\title{
A KRIMINALISZTIKA ÍGÉRETE
}

\section{THE PROMISE OF CRIMINALISTICS}

\author{
Finszter Géza \\ DsC, professor emeritus, Nemzeti Közszolgálati Egyetem Rendészettudományi Kar \\ proffinszter@gmail.com
}

\section{ÖSSZEFOGLALÁS}

\begin{abstract}
A kriminalisztika a 19. század végén megszületett bűnügyi tudomány, amelynek fő feladata a természettudományok eredményeinek felhasználása annak érdekében, hogy a bűnüldözés és a büntető igazságszolgáltatás az állam büntető hatalmát törvényes eljárásban, az igazság megállapítására alapozva érvényesítse. A nyomozástan tudománnyá emelkedésében meghatározó szerepe volt a büntetőjog humanizálódásának, a büntető anyagi és eljárási jogdogmatika fejlődésének és a természettudományok eredményeinek. A 21. század első két évtizede felszínre hozott olyan hatalmi törekvéseket, amelyek ezeket a korábban szilárdnak hitt alapértékeket komolyan veszélyeztetik.
\end{abstract}

\section{ABSTRACT}

The science of criminalistics as a discipline dealing with crime was born at the end of the $19^{\text {th }}$ century. Its main task is utilizing the results of natural sciences to enable the state to exercise its punishing power through law enforcement and criminal justice in lawful proceedings, based on the establishment of truth. Humanizing criminal law, development of substantial and procedural dogmatics of criminal law together with the development of natural sciences played a determinant role in lifting the investigation studies onto the level of science. In the first two decades of the $21^{\text {st }}$ century, such pursuits for power surfaced that seriously endanger the fundamental values believed to be solid before.

Kulcsszavak: a jog humánuma, jogalkotás, jogalkalmazás, megismerés, a múlt feltárása, bűnüldözés, jogállam

Keywords: humanism of law, legislation, implementation of law, understanding, exploring the past, persecution of crime, legal state

Büntetési tanok ritkán jelentkeznek a Magyar Tudományban. Ebben a terület kutatóinak restsége is közrejátszhat, de elképzelhető, hogy a kriminális elméletek nem eléggé „,elegánsak” ahhoz, hogy tekintélyes stúdiumok társaságában kapja- 
nak helyet. Múltjuk sem ad patinát, történetük alig kétszázötven éves. Túlontúl közel vannak az államhatalom józan praxisához, amelyben a hétköznapi feladatok minden más szempontot felülírnak. Minthogy a büntetés jogának forrása az állami impérium, annak intézményei a hatalom eszközei, és ezek nem mindig működnek rendeltetésszerüen. Erre számos példa volt a büntető igazságszolgáltatás múltjában. „A publicisztikában és a szakmunkákban is közkeletűvé vált Magyarországon a »koncepciós per« kifejezés. Ezek közé a politikai hatalom által megrendelt büntetőperek tartoznak, amelyeknek szinopszisát és benne az áldozatok bukását előre költötték (komponálták), és a teljes forgatókönyvet ennek alapján, itt-ott valóságos elemeket is alkalmazva utólag megírták, majd nagyrészt valótlan, költött, és akár tortúrával is kikényszerített vallomásokba foglalt elemek alapján lejátszatták." (Király, 2005, 223.)

Ezzel a súlyos örökséggel milyen esélyei vannak a kutatónak arra, hogy megismerje a bűnözés tényeit (amit a bünüldözés rejtőzködő természete elfed előle), hogy a gyakorlat kritikai elemzését elvégezze (amit a hierarchia nehezen visel), végül, hogy változásokat kezdeményezzen (amit az államhatalom illetéktelen beavatkozásnak tekint, vagy egyszerüen figyelembe sem vesz)?

Vannak korszakok, amikor a tudományosság kedvező társadalmi környezetre talál, de vannak mélypontok, amikor az esélyek jelentősen romlanak. A rendszerváltozások általában lendületet adnak az autonóm gondolkodásnak, a hatalom koncentrációja viszont gyanakvással fogadja a függetlenséget.

A büntetőjog tudományos megalapozása a társadalomtudományok önállósodásával kezdődött. Azt a kort, amelyben ezek a feltételek megteremtődtek Mannheim Károly ,a feudális életrend felbomlása” időszakára teszi, majd így folytatja: „Amíg a társadalmi egységek csak a vallási értelemadások közvetítésével voltak megragadhatók, és csak annyiban voltak láthatók, amennyiben összefüggésbe lehetett hozni őket Krisztus misztikus testével, addig nem jöhetett létre mai értelembe vett társadalomtudomány." (Mannheim, 1995, 32.)

A büntetési elméleteket Cesare Beccaria 1764-ben megjelent könyve emelte akadémiai szintre, amikor a spirituális világ helyett a tények felé fordította a figyelmet (Beccaria, 1967). A tények pedig azt mutatták, hogy a büntetőjog évezredeken keresztül nem volt egyéb, mint „tudás nélküli hatalom”, amelynek hatékonyságát az állam (alattvalóival egyetértésben) abban látta, hogy versenyre kel a bünözők kegyetlenségével. Ezt a viadalt gyakran az állam hóhérai nyerték meg.

Beccaria nyomán megfogalmazhatók a követelmények, amelyek segítségével a sötétség legyőzhető:

- a jog humánuma;

- a jogalkotásban az igazságosságot és a jogbiztonságot egyaránt céljának tekintő büntető anyagi és eljárási jog megteremtése; 
- a jogalkalmazásban a múlt igazsággal egyező megismerése törvényes eljárásban.

Az előbbiekben jelzett adottságok kizárólag a büntetőjogi jelenségek tudományos feltárásával válhatnak lehetőségből valósággá.

\section{A HUMÁNUM JOGA, A JOG HUMÁNUMA}

A humánumhoz való jog olyan értékrendre támaszkodik, amelynek a csúcsán az egyes ember méltósága kap helyet. A reneszánsz és a felvilágosodás kellő alapot nyújtott a fordulathoz, ami a 18. század teljesítménye volt. Az emberi méltóság sérthetetlensége azt jelenti, hogy nem lehetséges olyan nemesebb érdek, ami ezt a parancsot felülírhatja. Ha ugyanis ilyen érdek létezhet, akkor ennek oltárán az embereknek akár egész tömegei feláldozhatók. A huszadik század erre szörnyü példákkal szolgált. Sokáig úgy látszott, hogy a polgári társadalmak tanultak a múltból. (Az emberi méltóság sérthetetlenségét Alaptörvényünk is deklarálja!) Mégis, a humanista értékrend szüntelen fenyegetésnek van kitéve.

A kemény kéz politikájához való visszatérés vezető érve, hogy korunk bünözése soha nem tapasztalt veszélyeket hordoz. A veszélyforrások számbavételekor szükségszerüen érkezünk el a bünözés extrém formáihoz, mindenekelött a terrorizmushoz. „Sokan a 20. század második felének bünözésében bekövetkező újszerü jelenségeket: a terrorista akciókat és a túsz-szedést az érdekérvényesítés új megjelenési formájának tekintik. Ez a nézet tévesnek tűnik, mert - legalábbis ami a tartalmi lényegüket illeti - ezek az erőszakcselekmények sokkal régebbi időkben gyökereznek.” (Irk, 2012, 36.)

Ha a bünözés lényegében ma sem mutat más vonásokat - legalábbis a fenyegetések nagyságrendjében - mint századokkal ezelőtt, akkor ebből két következtetés vonható le.

Az egyik, hogy a bünüldözés és a büntető igazságszolgáltatás humanizálódásának folyamatai nem a bünözés megszelídülésével, hanem a büntető hatalom értékrendjének megváltozásával magyarázhatók. Azzal a felismeréssel, hogy a kegyetlenségre nem lehet válasz a hatalom kegyetlensége, a bünöző gátlástalansága nem ad jogot a hatalom önkényes gyakorlására, a bünözéstől való félelemre nem lehet gyógyír a hatalomtól való félelem, az igazságszolgáltatás hatékonyságának kulcsa az igazság megállapítása és nem az, hogy eljárásai és a szankciók mekkora rettegés kiváltására alkalmasak. Ezekre az eszmékre épülhetett a joguralom elve (nullum crimen... és a nulla poena... szabálya), az eljárási garanciák rendszere (a tisztességes eljárás követelménye), az igazságszolgáltatás függetlensége, és a büntetés-végrehajtás embersége. 
A másik következtetés az, hogy a bünözés addig nem tapasztalt formáinak megjelenése valóban új büntetőjogi megoldásokat sürget, de ez nem jelentheti a humánum feladását. A demokratikus jogállam büntetőjogát az jellemzi, hogy nem veszi át a bünözés logikáját és módszereit. Nem képzelhető el a veszélyeknek és fenyegetéseknek olyan szintje, amely indokolhatná a jogállami értékek elutasítását, minthogy ez utóbbi esetben maga az önkény állama jelentené a legnagyobb veszélyt az emberekre. A jogállami büntetőjog nem vált korszerütlenné, de kétségtelen, hogy rendkívül kényelmetlen az olyan hatalmi ambíciók számára, amelyek nem türik a korlátokat (Finszter, 2014, 9.).

A jog humánuma értéket képvisel, a jog ez által válik igazságossá. „Az igazságosság a modern polgári jogfilozófiai koncepcióban mindenekelőtt érték-problémát jelent: a jog és az igazságosság elsősorban érték-reláció... Csak az igazságos jog érvényes, az igazságtalan jog nem jog." (Peschka, 1972, 2010.) A humánumtól megfosztott büntetőnorma sem tarthat igényt a jog rangjára. A jogállamot alkotmányossá azok az értékek emelik, amelyek a jog évezredes fejlődése során kristályosodtak ki, és amelyeket csupán a törvényalkotás alaki szabályainak betartásával garantálni nem lehet.

\section{VÁLTOZÓ BÜNTETŐPOLITIKA ÉS A NORMATÍV TANOK}

A humánum eszméje reform jelentőségű büntetőpolitikát rajzolt. A polgári állam képes volt a büntetőjog és a büntetőeljárási jog kódexíróit hivatalnokokból tudósokká, a hivatalnokokat pedig autonóm személyiségekké emelni. A büntető anyagi és a büntető eljárási jog mủvelése a 19. században kapta meg tudományos alapjait, amelyek eredménye törvénykönyvekben testesült meg.

Magyarország ebben a folyamatban rangos helyet vívott ki magának, amit jól példáz a „kódexíró” Csemegi Károly munkássága. Az első magyar büntető törvénykönyv az ún. „egyesítési elmélet” talaján állt, ami az igazságosság és a hasznosság elveinek szintézisét jelenti. Az 1878. évi jogalkotás magáévá tette a következő felismerést: „Hogy a föltétlen igazság és a társadalom fenntartásának érdeke - vagyis az igazságos és a hasznos - a büntető rendszerben szükségszerüleg nevezetes tényezőt képeznek: ez magától értetődik, ez bizonyos tekintetben a józanésznek általánosan elterjedt tana." (Csemegi, 1880, 29.) Szó nincs tehát arról, hogy az értékek tisztelete lemond a hatékony védelemről. A büntetőjog humanizálása egyáltalán nem tette gyengévé a társadalmakat. Ellenkezőleg, a 19. század polgársága akár Párizsban, akár Londonban, akár Berlinben jóval nagyobb biztonságban élt, mint a nyilvános kerékbetörések idején. Ez igaz a kiegyezés korabeli Budára és Pestre is.

A büntető anyagi jog fejlődése mérföldes lépés volt az igazságosság felé. Meggyőző eredményt azonban csak az eljárásjoggal együtt lehetséges elérni. Az 1896. 
évi XXXIII. törvénycikkel kihirdetett büntető perrendtartást a korszak jogtudósa, Finkey Ferenc a következők szerint jellemezte: „A büntetőeljárás szabályai határozzák meg, mikor lehet az államban valakit letartóztatni, megmotozni, valakinek házát átkutatni, leveleit, küldeményeit, sajtótermékeit lefoglalni, tehát személyes szabadságától megfosztani, még mielőtt törvényesen elítélték volna. Alkotmányos állam, melyben a személyes és a politikai szabadság s a jogegyenlöség eszméi uralkodnak, természetesen úgy állapítja meg a büntetőeljárás szabályait, hogy az egyéni szabadságjogokat előzetesen minél ritkábban, csak fontos okból, szigorú formák mellett, kellő ellenőrzéssel és felelősség terhe alatt lehessen felfüggeszteniök az állam illetékes hatóságainak, a kényuralomnak pedig legelső teendője a büntető eljárást úgy szabályozni, hogy azzal hatalmát megszilárdíthassa, az egyéni- a sajtó- és a politikai szabadságot kénye szerint megszoríthassa $\mathrm{s}$ tönkretehesse azokat, a kik útjában állanak." (Finkey, 1908, 6.)

\section{AZ IGAZSÁG MEGISMERÉSE A BÜNTETŐELJÁRÁSBAN}

Amikor a büntetés elmélete a humanizálódás útját választotta, és a törvényalkotás ennek az értékelvnek a szolgálatába állt, számolt azzal is, hogy a bűnözés ettől nem szelídül meg. A jogalkotói dogmatika, a jövőre szóló tiltó parancs általános és belső ellentmondásoktól mentes normákba öntésének a tudománya találkozott a jog alapvető ellentmondásaival: a jogszabály a „kell”, a bekövetkezett bűncselekmény a „van” világa, a jogszabály általános, a jogsértés egyedi, a jogszabály a jövőnek szól, a deliktum a múlt ténye. Megismerhető-e ez a múlt az igazságnak megfelelően annak érdekében, hogy az állam az igazságszolgáltatás útján törvényes eljárásban legyen képes érvényesíteni büntető hatalmát, helyreállítva ezzel a megsértett jogrend tekintélyét?

A 19. század végén új bünügyi tudomány, a kriminalisztika lépett a színre azzal az ígérettel, hogy képes segítséget nyújtani ehhez a megismeréshez. Miért csak ilyen későn?

Először azért, mert a normatív bünügyi tudományok segédtudományaként akkor születhetett meg, amikor a tételes jogok már kivívták a maguk rangját az elméletekben.

Másodszor azért, mert amíg a nyomozás nem volt több az önkényes hatalomgyakorlás egyik eszközénél, sem a múlt megismerésének kötelessége, sem a múlt megismerésének szabályok közé szorítása nem jelentett kihívást. A kriminalisztika akkor vált nélkülözhetetlenné, amikor az államhatalom is a joguralom hatálya alá került.

Harmadszor pedig azért, mert a múlt valóságának megismeréséhez természettudományos eszközökre van szükség, és ezek a 19. század végére lettek elérhetöek a bűnüldözés számára. 


\section{JOGESET JOGSZABÁLY NÉLKÜL}

A jogfejlődést sokáig nem sújtotta, de nem is katalizálta a „van” és a „kell” ellentmondása. A jog legősibb formái nem is törvényekben, hanem a feltételezett jogsértést követő bírói döntésben testesültek meg. „A helyesre és helytelenre vonatkozó egyedüli mérvadó állítás a tények bekövetkezése után hozott bírói ítélet, amely nem tételez fel törvényt és annak megsértését, hanem amelyet egy felsőbb hatalom először súg a bíró fülébe a döntés pillanatában.” (Sumner Maine, 1997, 10.) Ehhez járult a jogi gondolkodás kezdeteinek ,hibrid” jellege, a magánjogi és a közjogi jogsértések megkülönböztetésének a hiánya. Ha a bün a tettes és a sértett jogvitája, akkor nem kell sem hatósági felhatalmazás, sem a múlt megismeréséhez szükséges különleges szaktudás. Az olyan döntési technikák, mint a megegyezés, ezt a magánviszony jelleget tükrözik. A középkori jogszolgáltatásnak különböző próbái pedig annak bevallása, hogy nem lévén tudásunk a konfliktus tárgyát képező múltbeli eseményről, a döntést transzcendens erőkre bízzuk (istenítélet).

\section{AZ ÖNKÉNYES HATALOMGYAKORLÁS}

Volt egy területe a társadalmi gyakorlatnak, ahol a jogviták eldöntését már az antikvitásban sem bízhatták spirituális módszerekre. Ez pedig a gazdasági élet, a termelés és a piac. A fejlett árutermelés a tulajdon védelmének és a szerződéseknek a világa. A múlt megismerésének igénye és annak racionális technikái mindenhol kifejlödnek, ahol gyarapodik a gazdaság és elsorvadnak ott, ahol a gazdálkodás primitív formái valósulnak meg. A nyomozás mint a múlt megismerésének mindennapi tapasztalatra építő módszere már jelen volt az antik társadalmakban, különösen a római jogban. Ezek a technikák tủntek el szinte teljesen a korai középkorban, párhuzamosan azzal, ahogyan a fejlett árutermelés helyébe a naturális gazdálkodás lépett. Az egyházi nagybirtokrendszer és a civil igazgatásra emlékeztető egyházi hierarchia az a terület, ahol a valóság megismerésének igénye fennmaradt. A püspöki vizitációk, a birtokon történtekről való általános tájékozódás (inquisitio generalis) és a felmerült jogsértések kikérdezéssel, tanúk felkutatásával való tisztázása (inqusitio specialis) voltak azok az egyházjogi eljárások, amelyek a 12. századtól fokozatosan a világi jogszolgáltatásnak is eszközei lettek. A nyomozás visszakerült a társadalmi konfliktusok rendezésére szolgáló fogások tárházába. Mindazonáltal a múltbeli események megismerése nem kizárólag a büntető hatalom sajátja volt, hanem általában a hatalomgyakorlás nélkülözhetetlen eszközeként szolgált. „A középkor Európájában ez az eljárás mindenekelött a kormányzás folyamatában az adminisztráció technikáiba, az ügyintézés menetébe illeszkedett, más szavakkal a nyomozás a hatalomgyakorlás meghatározott módozata lett." (Foucault, 1998, 61.) 


\section{A BÜNÜLDÖZÉS ÁLLAMOSÍTÁSA}

A büntetöjogi igény államosítása, amely csíráiban létezett már a görög és a római antikvitásban is, kiteljesedni csak a modern társadalmakban tudott. Mindez azt jelentette, hogy a sértett helyébe az állam képviselője, az ügyész lépett, aki a 12. századtól a középkor végéig nyomozó, vádló és bíró is egy személyben (Foucault, 1998, 62.). A vizsgálóbíró eredetileg bünügyi felügyelő volt, akinek nyomozói jogkörét I. Ferenc dekrétuma 1522-ben állapította meg. Ez a funkció egészen 1670-ig mind polgári, mind pedig büntetöügyekre illetékességet jelentett (Chambon, 1985, 3.). A büntető igazságszolgáltatás csak a 17. század végétől kapott önállóságot. A bünüldözés mint a büntető igazságszolgáltatás előkészítése pedig sokkal később, az 1897-es francia eljárási reformmal lett a büntetőeljárás jogilag is rendezett része. A tiszta inkvizíciós elv érvényesülése mellett már a rendőrségi nyomozásban is megjelentek a vádelv elemei (Di Marino, 1997). A folyamat betetózésének a 19. századi nagy európai kodifikáció tekinthető. Az eredmény az lett, hogy a büntetőfelelősség eldöntése az igazság megállapítására támaszkodik, az ehhez szükséges tényeket pedig a nyomozás során lehetséges feltárni. Megszülettek azok az állami hivatalok, amelyeknek elsődleges feladata a büntetőjogi szempontból releváns múlt megismerése lett, előbb az ügyész, majd a vizsgálóbíró, végül a bünügyi rendőrség.

\section{A JOGÁLLAM}

A kriminalisztika kései megjelenése azzal is magyarázható, hogy a valóság megismerésének szükséglete a leghatározottabban a szabad piacgazdaság igénye, amelynek a közjog világára gyakorolt hatásai csak a 19. századra értek meg. A polgári jogállam célnak tekinti a társadalomnak a büntől való megóvását, érvényesül a joguralom, a jogrend jogsértő módon nem védelmezhető, nincs mindenáron való jogérvényesítés, és a bűnüldözés kudarcaiért az államnak kell vállalnia a felelősséget. „Az anyagi igazságosság jogállami követelménye a jogbiztonságot szolgáló intézményeken és garanciákon belül maradva valósulhat meg. »Az anyagi igazság érvényesülésére« éppúgy nem biztosít (nem biztosíthat) alanyi jogot az Alkotmány, mint ahogy arra sem, hogy egyetlen bírósági ítélet se legyen törvénysértő. Ezek a jogállam céljai és feladatai, amelyek megvalósulása érdekében megfelelö - elsősorban eljárási garanciákat nyújtó - intézményeket kell létrehoznia, és az érintett alanyi jogokat garantálnia." (9/1992. (I. 30.) AB határozat)

A kriminalisztika tudománya a bizonyítás eszközeinek és módszereinek gazdagságát kínálja ahhoz, hogy a büntetőeljárás betölthesse küldetését: a büntetőjogi jelentőséggel bíró múlt igazsággal egyező megállapítását és a büncselekmény elkövetőjének azonosítását. Ennek ellenére a releváns múlt megismerése sokszor 
szinte leküzdhetetlen akadályokba ütközhet, és mindig fennáll a tévedés veszélye is. További gond, hogy a büntetőeljárásban feltárt tényállás igazságértékének ellenőrzésére nincsenek olyan objektív eszközök, mint a természettudományokban. Ilyet a kriminalisztika sem tud felkínálni. Ennek a helyzetnek a következményét az Alkotmánybíróság egy korábbi döntése a következők szerint vonta le: „A büntetőhatalom gyakorlására rendelt hatóságok mulasztása vagy a kézrekerítés eredménytelensége - mint kockázat - az államot terheli." (11/1992. (III. 5.) AB határozat)

Ha azonban a múlt megismerésének nehézségeit látva a büntető jogalkotás nem az eljárási garanciák és a bírósági tárgyalás rangjának megerősítésén munkálkodik, hanem az igazság megállapítását „valósághüségre” szelídíti, a hatékonyságot és az észszerü határidő betartásának célját minden más elé helyezi, a bírósági tárgyalás szerepét pedig korlátozza, akkor a törvénysértés kockázatát az államról a terheltre hárítja. Az ilyen kriminálpolitika nem csupán a jogállamiságot kérdőjelezi meg, hanem a kriminalisztika nyújtotta lehetőségeket is alábecsüli.

\section{A KRIMINALISZTIKA A TÁRSADALOMTUDOMÁNYOK HATÁRÁN}

A kriminalisztika a 19. század végén az osztrák Hans Gross és a francia Edmond Locard munkássága révén született szakkifejezés, ami eredetileg a bünügyi nyomozó speciális szaktudását kitöltő gyakorlati ismeretek együttesének a megjelölésére szolgált (Margot, 1999, 6.). Ehhez képest a kriminalista (ahogy nálunk sokáig nevezték, a detektív, vagyis a tények feltárója) olyan különleges ismeretek birtokosa, aki az ilyen tudást igénylő szakkérdések megválaszolásával, segíti a nyomozást. A különleges szakértelem alsó határát a kriminalisztikai szaktudás jelenti. Szakértöre akkor van szükség a nyomozásban, ha a szakkérdés eldöntéséhez a nyomozó (bünügyi technikus) szaktudása sem elegendő (Erdei, 1987, 31.). A kriminalisztikai tudásanyag rendszerezése és elméleti megalapozása, valamint új ajánlások kimunkálása a krimináltaktika, a kriminalisztika egyik ágának a feladata lett. A „tudományos rendőrség” a 20. század elején létesített rendőrségi azonosító laboratóriumok müködésének a megjelölésére szolgált, minthogy ezekben az intézetekben a kémia, a biológia, a fizika, az orvostudományok és más természettudományok képviselői, e tudományterületek által feltárt eszközök és módszerek segítségével igyekeztek segítséget nyújtani a tárgyi bizonyítékok felkutatásához, a múltbeli esemény rekonstruálásához, valamint az ehhez szükséges azonosítási mủveletek elvégzéséhez. A laboratóriumi háttér megkívánta a helyszínen folytatott nyomkutató és nyomrögzítő feladatok technikailag magas színvonalú elvégzését, ami a bünügyi nyomozó mellett újabb szakember, a bünügyi technikus tudásának a törzsét alkotta. Ezek az ismeretek a krimináltechnikában integrálódtak. A laboratóriumi szakértő és a bünügyi technikus bizonyítási tevékenységének próbáját jelentette, hogy megállapításaik és az általuk feltárt tárgyi 
bizonyítékok mennyire alkalmasak a büntetőperben az ítélethez szükséges belső meggyőződés kialakítására.

A kontinentális tárgyalási rendszer, ami inkább tekinthető a nyomozási anyag felmondásának, mint a tényállás megállapításához szükséges eredeti bizonyítás felvételének, a bűnügyi nyomozóknak és a bűnügyi technikusoknak a bíróság előtti szereplését a minimumra szorította, és ha az mégis bekövetkezett, a nyomozó kihallgatása inkább hasonlított „társhatóságok” közötti disputához, mint ügyféli közreműködéshez. Az angolszász rendszerü büntetőperben azonban az érdemi bizonyítás a tárgyaláson történik, ezért itt döntő jelentősége van annak, hogy a bünügyi nyomozás anyagának felkutatásában részt vett detektívek és bünügyi technikusok miként képesek érveiket a bíróság elé tárni. A laikus esküdtek számára bonyolult szakértői eljárásokat közérthető módon bemutatni - ez lett az egyik legfontosabb képesség. Csak az ilyen módon felvett bizonyítás teszi lehetővé a védelem számára az egyes bizonyítékok hitelt érdemlőségének ellenőrzését, és csak ennek révén lehetséges eljutni a kétségeket kizáró bizonyosságig. Az angolszász jogrendszer országaiban a kriminalisztikai szakismeret lényegét ennek a véleményformálásnak, valamint a vélemény igazságügyi fórumok elé terjesztésének a módszertana alkotta. Ezt a tudásanyagot nevezték forenzikus tudománynak (forensic science). Más értelmezés szerint a forenzikus tudományok körét az igazságügyi orvostan, a vegytan, a fizika és további olyan természettudományos háttérre támaszkodó igazságügyi tudományok képezik, amelyeknek közös ismérve, hogy saját szakterületük technikáit és módszereit a jogi eljárásokban felmerülö, különleges szakértelmet kívánó kérdések megválaszolásának szolgálatába állítják. Ebben a csoportosításban a kriminalisztika feladata ,a forenzikus tudományok számára egy általános elmélet és metodológia" kidolgozása (Kertész, 1972, 10.).

Az angol kifejezés, a forensic science szinte teljesen lefedi a kontinentális krimináltechnika fogalmát (Katona, 2002, 39.). Azonban a két eljárási rendszer konvergenciája a kriminalisztika szemantikájában is felismerhető. Katona Géza megállapítja, hogy a kriminalisztika kifejezés (és az ehhez kapcsolódó nyomozástani szemlélet) egyre inkább terjed az angolszász jogi kultúrában is. A már idézett Pierre Margot arra hívja fel a figyelmet, hogy a kontinentális gondolkodás viszont egyre nagyobb érdeklődést mutat a forenzikus tanítások iránt, olyannyira, hogy francia nyelvterületen terjedőben van az angol kifejezés megfelelöje, a sciences judiciaires (Margot, 1999, 6.). Sőt, a kriminalisztika müvelésében hírnevet szerzett lausanne-i egyetem „neológusai” már megalkották a francia sciences forensiques terminus technikust. Mindez nem csupán játék a szavakkal, hanem egyértelmü szemléletváltás. Az előkészítő szakaszt a következetes vádelv szeretné a laikus polgár akciójának láttatni, amellyel bíróság elé viszi a bủncselekmény okozta sérelmet. Ez olyan fikció, ami nem tartható fenn. A büncselekmény gyanújának felmerülésétől kezdődően jelen van a hatóság, a maga represszív felhatalmazásaival, amelyek ahhoz szükségesek, hogy az eljárás sikerét a büntetést 
kerülni kívánó érdekek ne veszélyeztethessék. De ugyanez a hatóság rendelkezik kriminalisztikai hozzáértéssel is, ami esélyt ad a múltbeli tényállás valósággal egyező megismerésének. A bünüldöző szervezet tagjával szemben támasztott szakmai követelmények teszik mind népszerúbbé a tengeren túl is a kriminalisztikai szemléletet, amelynek a bölcsője mégis csak a kontinentális eljárási forma. „Logikailag és történetileg is a büntetőeljárás a bünüldözéssel kezdődik, amelyben a büncselekmény felderítése, a bizonyítékok felkutatása, rögzítése, a feltételezett elkövető felderítése és esetleges elfogása is beletartozik." (Király, 2000, 17.)

Más oldalról viszont a tárgyalás felértékelödése a tényállás bizonyításában arra készteti a francia eljárási rendszeren nevelkedett bünügyi tisztviselőket, hogy legyenek képesek az általuk feltárt bizonyítékok hitelét a védelem érveivel szemben, egy kontradiktórius perben igazolni. Ez a forenzikus logika jellegzetes szereposztása.

A kriminalisztika tehát eredetileg úgy alakult ki, mint a bünüldöző apparátusok gyakorlati tapasztalatainak az összegzése, amely egyúttal a bünügyi nyomozótól elvárható nélkülözhetetlen szaktudás, gondolkodásmód és cselekvési készség együttesét jelentette. Ez a tudásanyag szervesen beépült a kriminalisztika tudományos rendszerébe, és akkor jutott el a társadalomtudományok határához, amikor a rendőrségi azonosító laboratóriumok rendszerén keresztül a természettudományok eredményeit a bünüldözés szolgálatába állította.

\section{A Jövő}

Amiért nincs ok aggodalomra, az a természettudományok lendületes fejlődése a digitális korszakban. A várható eredményekről e lapszámban is olvashatunk az igazságügyi genetikát bemutató tanulmányban (Pádár et al., 2020). A számítógépes automatizált szakértői rendszerek olyan meghökkentő eredményeket ígérnek, mint az ,agyolvasó” technikák, a DNS-azonosítás kiterjesztése az arcfelismerésre, a mobil helyszíni labor továbbfejlesztése, a daktiloszkópia tudományos alapokra helyezése. A titkos felderítés eszköztára akár több millió ember egy időben történő megfigyelésére ad lehetőséget (Fenyvesi, 2014, 231-243.). Mindez egyszerre biztató és félelmetes.

Amiért van ok aggodalomra, az a bünüldözés szervezetének konzervativizmusa és a jogállami értékek elutasításának növekvő népszerüsége.

\section{A BŨNÜLDÖZÉSI STRATÉGIA}

A hagyományos kriminalisztika az egyedi bünesetek megoldására koncentrált, és nem tekintette feladatának a bünözés átfogó tanulmányozását, amit meghagyott az ugyanabban az időben születő kriminológiának. Ez a képlet emlékeztet a de- 
tektívtörténetek szerkezetére, amelyben egy elkövetett büncselekménnyel szemben áll egy (rendszerint zseniális) nyomozó. A valóságban azonban a bünügyi rendőrségeknek, a bünüldöző hatóságoknak mindig a bekövetkezett büncselekmények tömegével kellett szembenézniük, amihez a kriminológiának nem volt sok szava, mert annak figyelmét a jövőben fenyegető bűnök megelőzése kötötte le. Különösen a bűnüldözés eredményességének hanyatlása sürgette bünüldözési stratégiák kialakítását, olyan szervezeti, jogi és müködési feltételek folyamatos és tervszerü biztosítását, amelyek nem csupán egyetlen deliktumra figyelnek, hanem a bünözés teljes terjedelmével szemben kívánnak hatékony megoldásokat. Erre a feladatra vállalkozik a stratégiai kriminalisztika.

A stratégiai kriminalisztika egyik új iránya a kriminalisztikai logisztika, amelyik a sikeres bűnüldözéshez szükséges tárgyi feltételek folyamatos biztosításának feltételeit tanulmányozza. Déri Pál a korszerü nyomozásról és az integrált bünüldözésről írt tanulmányában részletesen bemutatja azokat a krimináltaktikai megfontolásokat, amelyek eredményeként elérhető, hogy a felderítő beavatkozás az elkövetés helyéhez legközelebb, az elkövetés időpontjához képest a legkevesebb időveszteséggel történjék, mégpedig olyan módon, hogy a bünüldözés a legmagasabb szakértelmet és technikai készültséget mozgósítsa (Déri, 2004, 925-967.). A kriminalisztikai menedzsmentnek arra kell törekednie, hogy legyenek adottak a személyi feltételek. Ahhoz, hogy ezek a képességek sikerre vezessenek, a kriminalisztikai informatika új lehetőségeit szükséges használni, különösen pedig a számítógépes automatizált szakértői rendszereket és az ezekhez társuló korszerü nyilvántartásokat (Déri-Budai, 1991).

A rendőri megelözés túlsúlyba kerülése a represszióval szemben egy olyan átfogó kriminálstratégia megalapozásához vezethet, amely képes létrehozni a „bünfelderítés és a megelőzés egységes rendszerét” (Katona, 2001, 26-48.).

A kriminológia és a kriminalisztika kapcsolatáról írja Korinek László: „Mindkettő ténytudomány, abban az értelemben, hogy a bünözés valóságjelenségeit kutatja. Céljaik is közösek: a társadalomnak a bünözéstől való védelme. Konkrét kutatási területük vonatkozásában azonban már mutatkoznak különbségek. Míg a kriminológia mozgástere a kriminológiai büncselekmény-fogalom széles terrénuma, addig a kriminalisztikáé inkább a büntetőjogilag értékelhető emberi magatartás, tehát lényegében a büntetőjogi büncselekmény-fogalom sokkal egzaktabban meghatározott köre." (Korinek, 2010, 26.) A most idézett felismerések jelennek meg Viski László klasszikus kriminalisztika meghatározásában: „A kriminalisztika a büncselekmények nyomozásának, felderítésének tudománya. Célja, hogy a tételes jog által meghatározott keretekben olyan módszereket és eljárásokat dolgozzon ki, amelynek a segítségével a készülő büncselekmények leleplezhetők, megakadályozhatók, a már elkövetett büncselekmények felderíthetők, elkövetőjük megállapítható és felelősségre vonható..." (GaramvölgyiViski, 1961, 8.) 
Viski definíciójának máig ható értéke az, hogy a tételes jog tiszteletére tanít. Emlékeztet arra, miszerint csak a felderített bün tanulmányozása nyújt biztos alapokat a kriminológia társadalomvédelmi céljainak megvalósításához, feltéve, hogy a büntető igazságszolgáltatás az anyagi és eljárási jog érvényre juttatásával törvényesen és az igazság megállapításával védelmezi a jogrendet.

A kriminalisztikai stratégia vívmányai azonban csak akkor értékesíthetők, ha olyan kriminálpolitika kap elismerést, amely nem több és nem kevesebb, mint a büntető jogalkotás, a bünüldözés és a büntető igazságszolgáltatás bünözésre adott válaszstratégiáinak összessége. Alkotó folyamat, amelyben helyük van a bünügyi tudományoknak is. A büntető hatalom konzervativizmusa mindeddig sikeresen ellenállt egy ilyen kriminálpolitikának. Tanúi vagyunk a biztonság felértékelódésének a szabadsággal szemben, holott ezeket az értékeket nem szabadna egymással szembeállítani.

A kriminalitás démoni ábrázolása az ellenség büntetőjogának nevezett, új ideológiát teremtett, ami a büntettest ismét tárggyá degradálja (Nagy, 2013, 154.). Ebben a kriminalisztika védtelen, mert noha tudományos rangját a jogállam megszületésének köszönheti, és maga is közremüködött a büntetőjog humanizálásában, eszközei és módszerei diktatúrákat is szolgálhatnak. Idézzük Kulcsár Kálmán 1990-ből küldött üzenetét: Az állam „....akkor jogállam, ha a jogi értékekből fakadóan konkrét humanitással teli, s a jognak léte és érvényesülése csak akkor a jog uralma, ha ez a jog az ember személyiségét és szabadságát biztosítja éspedig itt és most. Vigyázzunk tehát - és ez a legfontosabb kötelességünk - a jog uralmának humánus tartalmára, a jog humánumára.” (Kulcsár, 1990, 558.)

A bünügyi tudományoknak nem lehet nemesebb feladatuk és fontosabb küldetésük, mint őrködni a büntetőjog humanizmusa felett.

\section{IRODALOM}

Beccaria, C. (1967): Büntett és büntetés. (ford. Sebestyén P.) Budapest: Akadémiai Kiadó Chambon, Pierre (1985): Le juge d' instruction. Paris: Dalloz

Csemegi K. (1880): A büntetö törvénykönyv anyaggyüjteménye I. kötet. Budapest

Déri P. (2004): Az állam és a társadalom kötelezettségei a bünözés elleni harcban. In: Bócz E. (föszerk.): Kriminalisztika II. Budapest: BM Kiadó, 925-968.

Déri P. - Budai A. (1991): Korszerü bünüldözés. Budapest: ORFK

Di Marino, G. (1997): L' implantation et les remises en cause des dogmes accusatoire et inqusitoire. Revue internationale de droit penal, 68, 1-2.

Erdei Á. (1987): Tény és jog a szakvéleményben. Budapest: Közgazdasági és Jogi Könyvkiadó

Fenyvesi Cs. (2014): A kriminalisztika tendenciái. Budapest-Pécs: Dialóg Campus Kiadó

Finkey F. (1908): A magyar büntetö eljárás tankönyve. Harmadik kiadás. Budapest: Politzer-féle Könyvkiadó Vállalat

Finszter G. (2014): Vállalható és nem vállalható társadalmi kockázatok. In: Gaál T. - Hautzinger Z. (szerk.): Pécsi Határör Tudományos Közlemények, XV. Pécs, http://pecshor.hu/periodika/ XV/finszter.pdf 
Foucault, M. (1998): Az igazság és az igazságszolgáltatás formái. (ford. Sutyák T.) Debrecen: Latin Betük Kiadó

Garamvölgyi V. - Viski L. (szerk.) (1961): Kriminalisztika. Általános rész. Budapest: BM Tanulmányi és Módszertani Osztály

Irk F. (2012): Kétkedö kriminológia, A rizikótársadalom kriminálszociológiája. Miskolc: Bíbor Kiadó, https://bit.ly/2TMogYg

Katona G. (szerk.) (2001): A kriminalisztika aktuális kérdései. Tanulmányok öt európai országból. Budapest: BM Kiadó

Katona G. (2002): A kriminalisztika és a bünügyi tudományok. Budapest: BM Kiadó

Kertész I. (1972): A tárgyi bizonyitékok elmélete a büntetőeljárási jog és a kriminalisztika tudományában. Budapest: Közgazdasági és Jogi Könyvkiadó

Király T. (2000): Büntetőeljárási jog. Budapest: Osiris Kiadó, 2003-as kiadás, https://regi.tankonyvtar.hu/hu/tartalom/tamop425/2011_0001_520_buntetoeljarasi_jog/ch28s02.html

Király T. (2005): Szemelvények ötven év büntetōjogi és más tárgyú tanulmányaiból. Budapest: ELTE ÁJK

Korinek L. (2010): Kriminológia I. kötet. Budapest: Magyar Közlöny Lap- és Könyvkiadó

Kulcsár K. (1990): Lehet-e demokrácia Magyarországon? Magyar Jog, 6-7.

Mannheim K. (1995): A gondolkodás struktúrái. (Kultúraszociológiai tanulmányok) Budapest: Atlantisz Kiadó

Margot, P. (1999): Un changement de nom dans la continuité. Revue Internationale de Criminologie et de police technique et scientifique, 1.

Nagy F. (2013): Régi és új tendenciák a büntetöjogban és a büntetöjog-tudományban. Budapest: Akadémiai Kiadó

Pádár Zs. - Kovács G. - Kozma Zs. (2020): Molekuláris bünjelek - Genetika a törvényszéken. Magyar Tudomány, 181, 5, 604-613.

Peschka V. (1972): A modern jogfilozófia alapproblémái. (Társadalomtudományi Könyvtár) Budapest: Gondolat Kiadó

Sumner Maine, H. (1997): Az ösi jog. (ford. Sárkány M.) Budapest: Gondolat Kiadó 